DOI https://doi.org/10.30525/978-9934-26-039-1-23

\title{
СОФІЙСЬКИЙ СОБОР - КРАСА, НАРОДЖЕНА 3 ПРОТЕСТУ (НА МАТЕРІАЛІ РОМАНУ ПАВЛА ЗАГРЕБЕЛЬНОГО «ДИВО»)
}

\author{
Коваленко I. B. \\ студентка першого року навчання магістратури \\ Інституту філології \\ Київського національного університету імені Тараса Шевченка \\ м. Київ, Украӥна
}

Твори Павла Загребельного $\epsilon$ помітним явищем українського літературного та культурного процесу XX століття й матеріалом для наукових розвідок.

Історична романістика, до якої належить «Диво» Павла Загребельного, показує Софійський собор як художній символ і як реальну історичну пам'ятку, що сконцентрувала в собі весь волелюбний, сильний дух народу, його невмирущість і нескореність.

Актуальність роботи полягає у вивченні феномену протесту, зумовленого русько-українською ментальністю, та в доведенні світовій спільноті, що праведна непокора породжує вічну красу.

Безліч дослідників звертали особливу увагу на тематику й проблематику історичної трилогії («Диво», «Смерть у Києві», «Первоміст»), вивчали їх структуру, стиль та мовні засоби, по-різному трактували образи героїв. Ми ж перед собою поставили дещо іншу мету роботи: довести, що саме протест героїв роману став поштовхом до створення неповторного собору - Софії Київської, а непереможний дух та ненависть до ворогів допомогли зберегти цю красу для майбутнього покоління; а також довести, що вивчення літературних творів сприяє популяризації пам'яток культури. Наукова новизна полягає в тому, що на матеріалі роману «Диво» вперше доведено унікальність слов'янської нації; з'ясовано сутність феномену протесту Павла Загребельного; глибоко розкрито психологію персонажів роману «Диво», які втілюють нескореність та внутрішній протест; уперше простежено причини появи саме таких моделей художніх образів; доведено, що Софія - великий культурний спадок, полишений нам історією, - сконцентрувала в собі весь волелюбний, сильний дух народу, його невмирущість та нескореність.

У романі «Диво» Софійський собор постає надважливою, всеосяжною спорудою, що об’єднує українців різних поколінь. 92 
В історичному творі незрівнянна церква побудована не з каміння та мармуру, у іiі основу закладено життєвий протест Павла Загребельного - творця роману; незламний дух Сивоока - головного зотчого; невпокірливу вдачу Ярослава Мудрого - князя, за часів правління якого звуки софійських дзвонів лунали по всій Русі-Україні; нездоланну жагу до перемоги Гордія Отави - вченого-захисника Софії Київської від ворожих німецьких снарядів; а також велич та самобутність самого храму, що впродовж тисячі років протидіє часові та щодня декларує неповторність української культури.

Павло Загребельний - невтомний шукач, експериментатор, вигадник, людина нестандартного мислення. Тяжкі життєві випробування породили непокору в душі письменника. Він починає боротися 3 неправдою, злом та приниженням людської гідності, відстоювати честь побратимів, викривати злочини радянської влади - саме внутрішній протест дав поштовх до створення оригінального історичного роману «Диво», що поєднує сучасне й минуле, засвідчує глибинність, унікальність, стійкість і нездоланність русько-української культури.

Усе найважливіше у творі пов'язане з образом вигаданого головного героя Сивоока, що уособлює незламний дух будівничих собору. У його уяві Софія мала стати символом Руси-України, саме тому хлопець протидіє примітивним методам тогочасних архітекторів, що лише знецінюють мистецтво. Зотчий заперечує наслідування й копіювання, кидає виклик візантійським майстрам, наважується критикувати владу. Саме 3 протесту миться народжується Софійський собор, що увібрав у себе традиції предків, самобутність русько-української культури.

Душа великого князя Ярослава Мудрого із самого дитинства сповнена суперечностей. Правитель зосереджується лише на грандіозних справах, прагне просвітити народ - так з'являється Софія. Саме собор повинен довести недругам, що держава єдина. Мудрий керманич ладен протистояти могутній Візантії, бо має високу мету - возвеличити країну. Ми бачимо непересічну особистість, внутрішній протест якої вивів державу на новий щабель розвитку, а також подарував усьому світові величну перлину русько-української середньовічно-християнської культури - Софію Київську.

Усі розділи роману, присвячені подіям Другої світової війни, відображають нездоланну жагу до перемоги Гордія Отави - вигаданого вченого-історика, що прагне відкрити всьому світові справжнє ім'я будівничого Софійського собору і тим самим довести унікальність, самобутність і неповторність культури Руси-України - саме цього так 
боялася нацистська ідеологія. Професор понад усе жадає зберегти Софію для майбутніх поколінь, не боїться віддати за неї власне життя.

Незмінним співгероєм у творі виступає Софійський собор. Храм виграв битву із візантійськими митрополитами, які боялися руськоукраїнської самобутності та прагнули будь-якою ціною домогтися уподібнення Софії константинопольській архітектурі. Собор розписаний фресками та мозаїками, бо чужі нам ромейські мармури, віддають вони холодом іншої культури, а барви народного майстра крізь віки зігріватимуть душі християн. Вершиною народної майстерності стала Оранта - символ вічного Києва, підтвердження того, що українська культура має глибоке коріння.

\section{Література:}

1. Бондаренко Ю. Феномен історичності в романі Павла Загребельного «Диво». Дивослово. 2010. № 4. С. 2-8.

2. Дімаров А. Павло Загребельний - з тих, які народжуються раз на століття. Голос України. 2009. № 167. С. 16.

3. Дончик В. Істина - особистість. Проза Павла Загребельного: літературно-критичний нарис. Київ, 1984. 248c.

4. Загребельний П. Диво. Роман. Харків, 2007. 638 с.

5. Загребельний П. Слово про Київ. Вітчизна.1982. № 5. С. $2-9$.

6. Загребельний П. Гомін давнини. Вітчизна. 1980. № 3. С. 20.

7. Загребельний П. Спроба автокоментаря. Неложними устами: Статті, есе, нариси. Київ, 1981. С. 14.

8. Загребельний П. Український шлях. - Публічна лекція в Національному університеті «Києво-Могилянська Академія». Зарубіжна лimepamypa. 2004. № 4. С. 18.

9. Загребельний П. Я обирав великі душі, які сяють нам тисячоліття. Вітчизна. 2004. № 7-8. С. 90-98.

10. Зборовська Н. Стильовий портрет шістдесятництва. Слово $i$ час. 2001. № 12. C. 40.

11. Осадча І. А що історія? Історія - коріння... Чим глибше, тим міцніше стоїмо (Образ Ярослава Мудрого в романі Павла Загребельного «Диво»). Дивослово. 1999. № 2. С. 39-41.

12. Панченко В. Замкнене коло нашої історії - ось це я мав на увазі. Дивослово. 1999. № 2. С. 42-45.

13. Сизоненко О. Мости літературної зрілості. Київ, 1974. С. 24.

14. Синьоок Т. Безсмертне диво творчості. Літературна газета. 2014. № 32. C. 1. 
15. Слабошицький М. Історичний дивосвіт Павла Загребельного (Шкіц до портрета). Дивослово. 2000. № 2. С. 57-59.

16. Фащенко В. Павло Загребельний. Київ, 1984. 206 с.

17. Чернов А. Щоб жити потрібні Вітчизна, свобода i пісня. Літературна Україна. 2014. № 33. С. 5.

18. Чумак Т. Проблема збереження духовності в романі Павла Загребельного «Диво». Українська література в загальноосвітній школі. 2004. № 10. С. $20-23$.

19. Шаховський С. Романи Павла Загребельного. Київ, 1974. 175 с.

DOI https://doi.org/10.30525/978-9934-26-039-1-24

\title{
ОСОБЛИВОСТІ ВІДБИТТЯ ТРАДИЦІЇ ВОЛОДИМИРА МАЯКОВСЬКОГО У ТВОРЧОСТІ МИХАЙЛА КУЛЬЧИЦЬКОГО
}

\author{
Козлова А. Г. \\ кандидат філологічних наук, дочент, \\ доиент кафедри зарубіжної літератури та слов'янських мов \\ Харківського національного педагогічного університету \\ імені Г. С. Сковороди \\ м. Харків, Украӥна \\ Козлов Є. Д. \\ кандидат філологічних наук, \\ доцент кафедри ділової іноземної мови та перекладу \\ Начіонального технічного університету \\ «Харківський політехнічний інститут» \\ м. Харків, Україна
}

Михайло Кульчицький - харківський поет, представник першого покоління радянських поетів, творчий шлях якого розпочався безпосередньо перед Другою світовою війною. I хоча загинув Кульчицький зовсім молодим (йому виповнилося лише 23 роки) i кількість творів, що лишилася нащадкам, невелика, але вірші поета увійшли до двохсоттомної «Бібліотеки всесвітньої літератури» (БВЛ) і перекладені багатьма мовами світу. Яскравий поетичний талант Кульчицького привернув до себе увагу сучасників поета, і вже багато років його творчість вивчається літературознавцями. Традиційно інформація про Кульчицького входить до оглядових статей, присвячених 